\title{
Pengaruh Marketing Mix terhadap Keputusan Wisatawan Mancanegara mengunjungi Ekowisata Mangrove di Tahura Ngurah Rai, Denpasar
}

Gusti Ayu Dwi Kurnia a,1 Gde Indra Bhaskara a,2

1gustiayudwikurnia@gmail.com2gbhaskara@unud.ac.id

a Program Studi Sarjana Destinasi Pariwisata, Fakultas Pariwisata, Universitas Udayana, Jl. Dr. R. Goris, Denpasar, Bali 80232 Indonesia

\section{ABSTRACT}

Marketing is one of the important strategies in tourism activities. With the marketing, tourists know the tourist attraction that will be visited. Marketing consists of several aspects, such as product, place/distributions, price and promotion (marketing mix). This research was conducted to determine the form of marketing mix at Tahura Ngurah Rai Mangrove Ecotourism and measure how much influence the marketing mix had on the decisions of foreign tourists visiting Tahura Ngurah Rai Ecotourism. The method used in research is quantitative method. Data collection is conducted by questionnaire, observation, and literature study. While the data analysis technique used is the Important Performance Analysis (IPA) technique.

The results of study showed that the components of the marketing mix consisting of products, prices, places / distributions, and promotions still did not meet the level of tourists satisfaction, There were still several components that had to be increased such as price and place. Therefore, the manager must focus on to the component that doesn't meet the level of tourist satisfaction since it can influence the tourist visiting decisions.

Keywords : Marketing Mix, Ecotourism, Tahura Ngurah Rai

\section{PENDAHULUAN}

Pemasaran merupakan salah satu strategi dalam pariwisata yang dapat digunakan untuk menarik kunjungan wisatawan ke suatu daya tarik wisata. Produk-produk yang berorientasi pasar dengan mempertimbangkan daya dukung lingkungan akan mampu memberikan kontribusi yang optimal pada suatu daya tarik wisata. Oleh karena itu, kualitas dari suatu produk menjadi hal yang penting dan perlu diperhatikan dalam pengembangan pariwisata.

Pulau Bali merupakan salah satu destinasi pariwisata dengan angka kunjungan wisatawan yang cukup tinggi dibanding daerah-daerah lainnya di Indonesia dengan persentase kunjungan wisatawan mancanegara ke Indonesia pada tahun 2017 sebesar 21,88\% dan Bali sebesar 15,62\% (BPS Provinsi Bali, 2018). Dengan demikian ini membuktikan bahwa pulau Bali masih menjadi tujuan utama pariwisata dunia. Namun tingginya kunjungan wisatawan ke Bali ternyata tidak berpengaruh banyak terhadap kunjungan wisatawan ke beberapa daya tarik wisata yang ada di Denpasar seperti ekowisata Mangrove yang ada di Tahura Ngurah Rai yang hanya mampu menarik 1.103 kunjungan pada tahun 2016 (www.disparda.baliprov.go.id).

Ekowisata Tahura Ngurah Rai merupakan salah satu produk wisata alam berupa hamparan hutan mangrove yang menjadi salah satu tujuan wisata alternatif bagi wisatawan yang berkunjung ke kota Denpasar. Daya tarik wisata ini memiliki lokasi yang sangat strategis karena letaknya berdekatan dengan kawasan wisata Sanur, Kuta, Nusa Dua dan bandara Ngurah Rai. Akan tetapi daya tarik wisata ini masih memiliki beberapa masalah dalam pengembangannya, seperti banyaknya sampah yang terdapat di sekitar jalan menuju ekowisata, kerusakan papan yang digunakan sebagai jalur treking, perbedaan harga tiket yang sangat besar antara wisatawan domestik dan mancanegara, serta minimnya kegiatan promosi yang dilakukan.

Oleh karena itu, penelitian ini bertujuan untuk mengetahui bentuk dari marketing mix yang terdiri dari produk, harga, saluran distribusi, dan promosi pada ekowisata mangrove Tahura Ngurah Rai, serta mengetahui seberapa besar pengaruh marketing mix terhadap keputusan wisatawan mancanegara berkunjung ke ekowisata mangrove tersebut.

\section{TINJAUAN PUSTAKA}

\subsection{Telaah Hasil Penelitian Sebelumnya}

Penelitian mengenai pemasaran yang digunakan sebagai acuan dalam penelitian ini yang pertama adalah penelitian dari Muntadliroh (2016) dengan judul "Strategi Komunikasi Pemasaran Terpadu Ekowisata di Kebun Raya Eka Karya, Bedugul Bali". penelitian ini lebih mengacu pada strategi pemasaran melalui promosi. Sedangkan 
penelitian kedua dari Adelianie (2015) dengan judul "Alasan dan Hambatan Penyajian Buah Lokal dalam Operasional Hotel Berbintang di Sanur". Penelitian ini dilakukan dengan pendekatan bauran pemasaran (marketing mix).

\subsection{Landasan Konsep}

Untuk menganalisis permasalahan yang terdapat dalam penelitian ini, digunakan beberapa konsep yaitu konsep ekowisata (Fandeli,2002), konsep pemasaran (Kotler dan Keller dalam Dharmmesta, 2014),konsep marketing mix (Kotler dalam Kertajaya, 2010) yang terdiri dari produk (product), tempat/distribusi (price), harga (price), dan promosi (promotion)

\section{METODE}

Penelitian ini menggunakan metode kuantitatif, dimana definisi operasional variabel digunakan sebagai batasan dalam permasalahan. Adapun variabel yang digunakan terdiri dari independen variable atau variabel bebas (X) yaitu terdiri dari produk, harga, tempat dan promosi. Dan dependen variable atau variabel terikat yang terdiri dari keputusan wisatawan mancanegara untuk berkunjung.

Jenis data berupa data kuantitatif dan kualitatif. sedangkan sumber data diperoleh dari data primer, data sekunder. Sedangkan teknik pengumpulan data diperoleh dari hasil kuisioner, observasi dan studi kepustakaan. Sedangkan Teknik analisis yang digunakan dalam penelitian ini menggunakan teknik importance performance analysis (IPA)Martilla dan James (1977) dalam Tjiptono (2011). Dengan menggunakan teknik sampling jenuh menurut Sugiyono (2012) dikarenakan jumlah sample kurang dari 30 orang.

\section{HASIL DAN PEMBAHASAN}

\subsection{Gambaran Umum Lokasi Penelitian}

Ekowisata Mangrove merupakan salah satu pengembangan pariwisata berbasis wisata alam yang terletak di kawasan sepanjang pantai Sanur hingga pantai Tanjung Benoa. Di sebelah timur terdapat Pantai Sanur, barat Pantai Kuta dan sebelah selatan kawasan Nusa Dua. Ekowisata mangrove ini Secara geografis terletak 1159'11514 Bujur Timur dan 849' Lintang Selatan.
Sedangkan secara administrasi pengelolaan kawasan ekowisata mangrove Taman Hutan Raya Ngurah Rai termasuk dalam wilayah UPT. Tahura Ngurah Rai, Dinas Kehutanan Provinsi Bali.

\subsection{Bentuk Marketing Mix Pada Ekowisata Mangrove}

a. Produk (product)

Ekowisata mangrove di Tahura Ngurah Rai memiliki produk pariwisata berupa lingkungan alam dan keanekaragaman hayati berupa hamparan hutan mangrove, keberagaman hewan seperti burung, biawak. ikan, dan kepiting serta pantai. Disini wisatawan dapat melakukan kegiatan wisata berupa memancing, dan menikmati pemandangan alam, serta pengamatan burung dan treking.

\section{b. Harga (price)}

Untuk dapat memasuki kawasan ekowisata mangrove, wisatawan dikenakan biaya tiket sebesar 10.000 ribu rupiah untuk wisatawan domestik dan 200.000 ribu rupiah untuk wisatawan mancanegara. Dengan harga tersebut fasilitas yang didapatkan wisatawan dalam melakukan wisata adalah bird watching, treking, informasi terkait keanekaragaman vegetasi pada ekowisata mangrove, fishing namun dengan membawa peralatan sendiri. Tersedia juga toilet, rest area, tempat parkir, dan tempat penjualan makanan dan minuman dan loket tiket.

\section{c. Tempat/Distribusi (place)}

Ekowisata mangrove terletak di Jalan Bypass Ngurah Rai, letaknya mudah untuk ditemukan karena berada pada jalur pariwisata yaitu Sanur, Kuta dan Nusa Dua. Sejauh ini belum ada kerjasama yang dilakukan pihak pengelola dalam memasarkan produk ekowisata ini dengan travel agent maupun pihak swasta lainnya. Sehingga wisatawan yang melakukan pembelian pada ekowisata mangrove secara langsung datang ke lokasi tanpa adanya perantara distribusi yang dilakukan. Ekowisata mangrove ini memiliki jumlah produk pariwisata yang beragam didalamnya, seperti keanekaragaman vegetasi mangrove, beberapa atraksi wisata dan ketersedian fasilitas penunjang ekowisata.

\section{d. Promosi (promotion)}

Dalam mempromosikan ekowisata mangrove di Tahura Ngurah Rai, tidak terlihat 
adanya promosi yang dilakukan oleh pihak pengelola, informasi mengenai keberadaan ekowisata mangrove selama ini hanya tersedia pada website resmi dinas perhutanan Provinsi Bali dan beberapa review dari blog-blog yang tersedia pada media online. Yang tentunya media-media tersebut tidak memberikan informasi yang lengkap mengenai ekowisata mangrove di Tahura Ngurah Rai.

\subsection{Pengaruh Marketing Mix terhadap Keputusan Wisatawan Mancanegara Berkunjung ke Ekowisata Mangrove}

Untuk mengetahui seberapa besar pengaruh marketing mix terhadap keputusan wisatawan mancanegara mengunjungi ekowisata mangrove Tahura Ngurah Rai, digunakan teknik analisis Important Performance Analisys (IPA). Teknik ini digunakan untuk mengukur seberapa besar tingkat kepuasan wisatawan terhadap bentuk dari marketing mix pada ekowisata mangrove tersebut dan seberapa besar elemen dari marketing mix penting bagi wisatawan sehingga mampu mempengaruhi wisatawan untuk melakukan kunjungan ke ekowisata mangrove Tahura Ngurag Rai.

Adapun langkah-langkah yang dilakukan dalam perhitungan pada teknis analis IPA adalah sebagai berikut:

\section{Tingkat Kesesuaian}

Dengan membandingkan tingkat kepuasan dengan tingkat kepentingan pada marketing mix maka akan diketahui urutan prioritas dalam pengaruh kunjungan wisatawan. Berdasarkan hasil penyebaran kuisioner maka didapat tingkat kesesuaian sebagai berikut :

a. Menghitung skor indikator kepuasan (X) dan kepentingan (Y) pada variabel marketing mix

Contoh perhitungan dengan variabel product indicator ketersedian fasilitas pada ekowisata mangrove, didapat hasil sebagai berikut:

Skor Kepuasan (Xi) $\quad=(5 \times 5)+(4 x$ 8) $+(3 \times 4)+(2$ x 3$)+(1 \times 3)$

$$
=78
$$

Skor Kepentingan (Yi) $\quad=(5 \times 3)+(4 \times$ 12) $+(3 \times 8)+$
$(2 \times 0)+(1 \times 0)$

$=87$

b. Menghitung Tingkat Kesesuaian

Setelah menghitung skor masing-masing indikator pada setiap variabel dalam marketing mix, selanjutnya dilakukan perhitungan tingkat kesesuaian (Tki) dengan cara membagi skor kepuasaan (Xi) dengan skor kepentingan (Y) dikali dengan 100\%, kemudian dilakukan perhitungan tingkat kesesuaian totalnya. sehingga di dapat hasil seperti dibawah ini.

Tingkat kesesuaian (\%)

$T k i=\frac{\sum \mathrm{Xi}}{\sum \mathrm{Yi}} x 100 \%$

$T k i=\frac{78}{87} \times 100 \%$

$\mathrm{Tki}=89,65 \%$

Perhitungan tersebut berlaku untuk semua indikator pada variabel marketing mix sehingga dari perhitungan tersebut akan didapat hasil tingkat kesesuaian pada setiap indicator yang nantinya digunakan untuk melihat tingkat prioritas dari indikator tersebut.

Setelah dilakukan perhitungan tingkat kesesuaian untuk masing-masing indikator selanjutnya dihitung rata-rata nilai dari seluruh tingkat kesesuaian tersebut, Dimana nilai rata-rata dari tingkat kesesuaian tersebut adalah $78.45 \%$. artinya karena rata-rata tingkat kesesuaian ini kurang dari 100\% berarti tingkat kesesuaian antara tingkat kepuasan wisatawan dengan tingkat kepentingan wisatawan dianggap tidak mempengaruhi keputusan wisatawan untuk berkunjung ke ekowisata mangrove.

Hal selanjutnya yang dilakukan adalah membuat diagram kartesius, untuk mengetahui posisi indikator pada variabel marketing mix tersebut masuk dalam kuadran berapa dalam mempengaruhi keputusan wisatawan berkunjung ke ekowisata mangrove. Langkah yang dilakukan adalah sebagai berikut:

2. Menghitung rata-rata atribut kepuasan (X) dan tingkat kepentingan (Y) yang menjadi batas pada diagram kartesius 
Langkah selanjutnya yaitu menghitung rata-rata atribut $X$ dan $Y$, ini dilakukan untuk dapat memetakan atribut mana saja yang memiliki pengaruh dan kurang bahkan tidak berpengaruh terhadap keputusan wisatawan mancanegara dalam berkunjung ke ekowisata Tahura Ngurah Rai, Sebagai contoh untuk menghitung nilai rata-rata kepuasan untuk indikator ketersedian fasilitas pada variabel produk ekowisata mangrove dihitung dengan cara

$$
\bar{X}=\frac{78}{23}
$$$$
\bar{X}=3,39
$$

Sedangkan untuk menghitung nilai rata-rata kepentingan untuk indikator ketersedian fasilitas pada variabel produk ekowisata mangrove dihitung dengan cara

$\bar{Y}=\frac{87}{23}$

$\bar{Y}=3,78$

3. Menghitung rata-rata seluruh atribut kepuasan $(\overline{\bar{X}})$ dan tingkat kepentingan $(\bar{Y})$ yang menjadi batas pada diagram kartesius, dihitung dengan cara:

Pada penelitian ini diagram kartesius digunakan untuk menghitung tingkat keputusan wisatawan berdasarkan masingmasing variabel dalam marketing mix yang terdiri dari produk, harga, tempat dan promosi. Untuk itu diperlukan penghitungan rata-rata atribut untuk setiap variabel dari marketing mix yang nantinya akan menjadi rata-rata batas atribut kepuasan $(\overline{\bar{X}})$ dan ratarata batas atribut kepentingan $(\overline{\bar{Y}})$ dalam diagram kartesius. adapun perhitungan yang dilakukan adalah sebagai berikut:

Contoh perhitungan pada variabel produk

$\overline{\bar{X}}=\frac{\sum_{i=1}^{n} \bar{X} 1}{K}$

$\overline{\bar{X}}=\frac{15.35}{5}$

$\overline{\bar{X}}=3.07$

$\overline{\bar{Y}}=\frac{\sum_{i=1}^{n} \bar{Y} 1}{K}$

$\overline{\bar{Y}}=\frac{20.26}{5}$

$\overline{\bar{Y}}=4.05$

Dari hasil perhitungan tersebut maka diketahui bahwa batas diagram pada diagram kertasius variabel produk pada sumbu $X$ adalah 3.07 sedangkan pada sumbu Y adalah
4.05. perhitungan tersebut berlaku juga pada variabel harga, tempat/distribusi dan promosi.

Setelah melakukan perhitungan melalui diagram katesius, maka akan didapat hasil atribut-atribut yang mempengaruhi wisatawan dalam berkunjung ke ekowisata mangrove Tahura Ngurah Rai. pada matrik ini tingkat kepuasan dikaitkan dengan tingkat kepentingan pada setiap indikator dari marketing mix. Sehingga dapat diiketahui indikator tersebut masuk dalam kuadran A yang artinya faktor-faktor yang dianggap penting dan atau diharapkan konsumen akan tetapi kinerja perusahaan dinilai belum memuaskan sehingga pihak perusahaan perlu berkonsentrasi untuk mengalokasikan sumber dayanya guna meningkatkan performa yang masuk pada kuadran ini, kuadran B artinya faktor-faktor yang dianggap penting dan diharapkan sebagai faktor penunjang keputusan konsumen sehingga perusahaan wajib untuk mempertahankan prestasi kinerja tersebut , kuadran C yang artinya faktor-faktor yang dianggap mempunyai tingkat persepsi atau kinerja aktual yang rendah dan tidak terlalu penting dan atau tidak terlalu diharapkan oleh konsumen sehingga perusahaan tidak perlu memprioritaskan atau memberikan perhatian lebih pada faktorfaktor tersebut.atau kuadran D yang artinya faktor-faktor yang dianggap tidak terlalu penting dan tidak terlalu diharapkan oleh pelanggan sehingga perusahaan lebih baik mengalokasikan sumber daya yang terkait pada faktor tersebut kepada faktor lain yang lebih memiliki tingkat prioritas lebih tinggi. sehingga di peroleh hasil sebagai berikut:

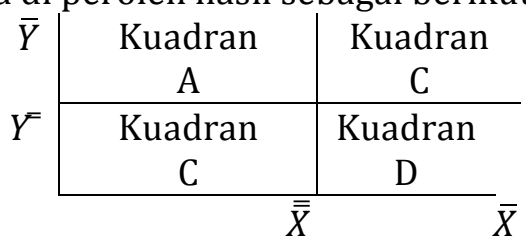

Diagram Kartesius

Sumber : Tjiptono, 2011

\section{a. Analisis Pengaruh Produk Terhadap Keputusan Wisatawan}




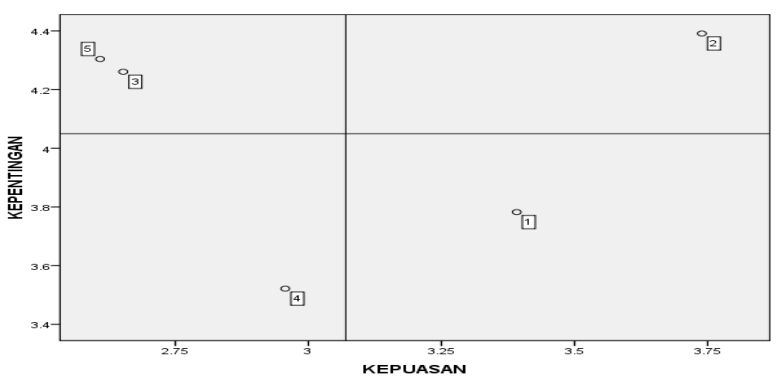

Gambar 1. Diagram kartesius variabel produk

Sumber : Pengolahan data 2018

Pada variebel produk terdapat 5 indikator produk yang digunakan. Berdasarkan penggambaran diagram kartesius tersebut dapat terlihat bahwa indikator produk 2 yaitu pada pernyataan ekowisata mangrove memiliki panorama alam yang indah dan keanekaragaman vegetasi didalamnya terletak di kuadran B, yang artinya indikator ini memiliki tingkat kepuasaan yang memuaskan bagi wisatawan dan dianggap salah satu faktor penting dalam pengambilan keputusan wisatawan dalam mengunjungi ekowisata mangrove. Hal ini didukung juga karena pada ekowisata mangrove terdapat vegetasi yang beragam seperti hutan mangrove, dan beberapa jenis hewan seperti biawak, ikan, dan jenis burung. Indikator pada nomor 3 dan 5 yaitu terkait kemanan dan kenyamanan jalur treking serta kebersihan lingkungan yang terletak di kuadran A. Hal ini dikarenakan jalur treking mengalami kerusakan di beberapa tempat, papan kayu yang digunakan sebagai jalur treking mulai rapuh dan bolong, akibat hal tersebut tidak jarang wisatawan jatuh saat treking tentunya hal tersebut dapat mengganngu keamanan dan kenyamanan wisatawan dalam berwisata di ekowisata mangrove.

Indikator nomor 4 terkait pelayanan jasa yang didapatkan wisatawan selama melakukan wisata masuk dalam kuadran C. artinya indikator ini dianggap tidak terlalu penting dalam mempengaruhi keputusan wisatawan untuk berkunjung dan kenyataannya sudah memenuhi kepuasan wisatawan. Sedangkan untuk indikator yang masuk dalam kuadran D adalah indikator nomor 1 terkait kebersihan, indikator ini dianggap tidak terlalu penting dalam mempengaruhi keputusan wisatawan dalam melakukan kunjungan, hal ini terlihat dari walaupun wisatawan menyadari bahwa kebersihan lingkungan di ekowisata mangrove masih tergolong kurang bersih, akan tetapi wisatawan tersebut tetap melakukan kunjungannya ke ekowisata mangrove. Dari segi kepuasan sejauh ini wisatawan merasa cukup puas terhadap upaya pengelola dalam mengatasi sampah plastik yang ada pada aliran sungai tersebut, karena pihak pengelola kerap melakukan pembersihan pada lingkungan ekowisata mangrove.

\section{b. Analisis Pengaruh Harga (Price) Terhadap Keputusan Wisatawan}

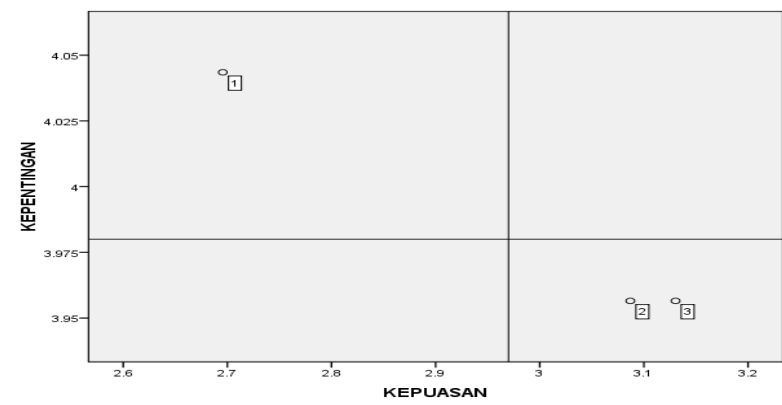

Gambar 2. Diagram Kartesius variabel harga Sumber : Pengolahan data 2018

Pada variabel harga (price) terdiri dari 3 indikator pengukuran, dari diagram diatas dapat dilihat bahwa indikator 1 pada variabel harga terkait keterjangkauan harga tiket masuk dalam kuadaran A yang artinya indikator tersebut dinilai sangat penting dalam mempengaruhi keputusan wisatawan berkunjung, namun dengan harga sebesar sebesar 200.000 rupiah per orang bagi wisatawan mancanegara, dinilai kurang terjangkau sehingga menimbulkan ketidakpuasan

Sedangkan untuk indikator 2 dan 3 terkait dengan kesesuaian harga tiket dengan fasilitas dan kesesuaian harga tiket dengan kualitas pelayanan yang diberikan masuk dalam kuadran D, yang artinya bahwa indikator tersebut bukan indikator yang penting dalam mempengaruhi keputusan wisatawan untuk berkunjung ke ekowisata mangrove. Namun indikator tersebut menunjukkan adanya tingkat kepuasan yang cukup terhadap kualitas pelayanan dan fasilitas yang ada pada ekowisata mangrove. 


\section{c. Analisis Pengaruh Tempat / Distribusi (Place) terhadap Keputusan Wisatawan}

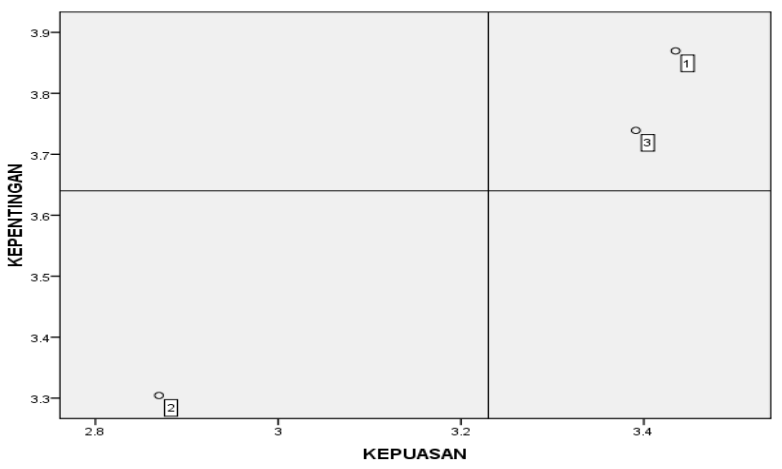

Gambar 3. Diagram Kertesius Variabel tempat/distribusi

Sumber : Pengolahan data 2018

Pada variabel tempat (place) atau distribusi digunakan 3 indikator penilaian untuk mengetahui pengaruh keputusan wisatawan berkunjung ke ekowisata mangrove. Berdasarkan hasil perhitungan dan pada diagram diatas terlihat bahwa indikator yang memiliki pengaruh penting dalam keputusan wisatawan mancanegara mengunjungi ekowisata mangrove adalah indikator nomor 1 dan 3 yaitu lokasi yang strategis dan lingkungan yang masih alami. Letak ekowisata yang berada jalan Bypass Ngurah Rai dianggap strategis dan mudah dijangkau dengan kendaraan apapun sehingga kedua indikator tersebut memiliki tingkat kepuasan yang cukup bagi wisatawan.

Sedangkan untuk indikator nomor 2 yaitu terkait saluran distribusi salah satunya dengan travel agent dianggap tidak terlalu memuaskan dan bukan merupakan hal penting dalam mempengaruhi wisatawan berkunjung ke ekowisata mangrove, ini dikarenakan wisatawan bisa datang dengan sendirinya tanpa melalui perantara pembelian mengingat lokasinya mudah ditemukan oleh wisatawan.

\section{d. Analisis Pengaruh Promosi (Promotion) terhadap Keputusan Wisatawan}

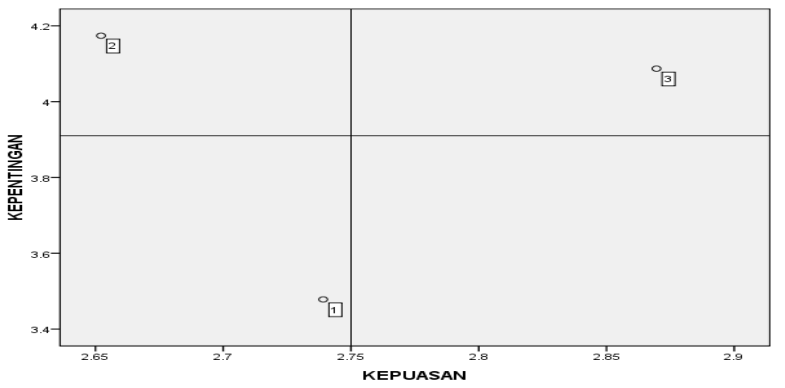

Gambar 4. Diagram Kartesius variabel promosi Sumber : Pengolahan data 2018

Pada variabel promosi terdapat 3 indikator yang digunakan untuk mengetahui keputusan wisatawan berkunjung ke ekowisata mangrove. Dari hasil perhitungan dan berdasarkan diagram diatas diketahui bahwa yang mempengaruhi keputusan wisatawan berkunjung ke ekowisata mangrove adalah indikator nomor 3 yaitu terkait dengan citra pada ekowisata yang masuk dalam kuadran B, indikator ini dianggap penting dan dirasa sudah mampu memberikan kepuasan wisatawan dalam berkunjung ke ekowisata mangrove ini.

Selanjutnya untuk indikator yang masuk dalam kuadran A adalah indikator nomor 2 terkait dengan promosi melalui media online maupun offlline (artikel, bulletin, leaflet, booklet, brosur, foto, website, majalah, koran atau media sosial). Wisatawan merasa bahwa informasi yang tersedia tentang keberadaan ekowisata ini masih tergolong minim. Wisatawan kebanyakan mengetahui keberadaan ekowisata mangrove ini melalui rekan dan keluarganya masing-masing dan beberapa dari foto-foto media sosial yang diunggah oleh orang-orang yang pernah berkunjung ke ekowisata ini sebelumnya. Sejauh ini belum ada brosur ataupun promosi yang dilakukan oleh pihak pengelola dalam menarik kunjungan wisatawan ke ekowisata mangrove. Tentunya hal ini dianggap penting bagi wisatawan sehingga wisatawan dapat lebih mengetahui mengenai produk yang ada pada ekowisata mangrove tersebut. oleh karena itu, indikator ketersedian informasi pada variabel promosi ini dianggap wisatawan kurang memuaskan. 
Sedangkan untuk indikator 1 terkait pembelian secara langsung oleh pengelola kepada wisatawan (personal selling) masuk dalam kuadran $\mathrm{C}$. hal ini dianggap wisatawan tidak terlalu penting dilakukan pihak pengelola karena bukan salah satu yang mempengaruhi keputusan wisatawan untuk mengunjungi ekowisata mangrove sehingga pada indikator ini memiliki tingkat kepuasan yang rendah.

\section{SIMPULAN DAN SARAN}

\section{a. Simpulan}

Berdasarkan hasil analisis dan pembahasan sebelumnya, dapat ditarik kesimpulan bahwa daya tarik ekowisata mangrove di Tahura Ngurah Rai dilihat dari komponen marketing mix yaitu produk, harga, tempat/distribusi dan promosi masih perlu di tingkatkan hal ini dikarenakan wisatawan masih merasa belum puas terhadap apa yang disuguhkan oleh daya tarik wisata ini. Hal-hal yang yang dirasa belum memenuhi kepuasan wisatawan mancanegara dalam berkunjung ke ekowisata ini terkait kurangnya promosi, harga tiket masuk yang dikenakan bagi wisatawan mancanegara dinilai terlalu tinggi. masalah kebersihan lingkungan dan keamanan jalur treking. Namun disamping itu, jika dilihat secara keseluruhan berdasarkan tingkat kesesuaian rata-rata variabel memiliki nilai $78,45 \%$ artinya secara keseluruhan marketing mix cukup mempengaruhi keputusan wisatawan mancanegara dalam mengunjungi ekowisata mangrove ini.

\section{b. Saran}

Berdasarkan penelitian tersebut adapun saran yang dapat peneliti berikan adalah Bagi pihak pengelola disarankan untuk lebih meningkatkan kinerja kinerja dari 4 indikator dalam kuadran A terkait kebersihan, keamanan jalur treking, keterjangkauan harga tiket, dan promosi melalui media online maupun offline. Mengingat keempat indikator tersebut merupakan indikator yang dianggap penting bagi wisatawan dalam mempengaruhi keputusan berkunjungnya ke ekowisata namun dari tingkat kepuasan wisatawan belum merasa puas terhadap keempat indikator tersebut.
Sedangkan untuk indikator tertentu pengelola harus mempertahankan kualitas dari indikator yang masuk dalam kuadran B yaitu terkait dengan panorama dan keanekaragaman vegetasi, kemudahan akses, dan citra dari ekowisata yang dinilai masih baik dari wisatawan.

\section{DAFTAR PUSTAKA}

Adelianie, I. Gusti Agung Diah. "Alasan Dan Hambatan Penyajian Buah Lokal Dalam Operasional Hotel Berbintang Di Sanur." Jurnal Master Pariwisata 2.1 (2015): 1-1.

Badan Pusat Statistik Provinsi Bali. 2018. Direktori 2018. Bali.

Fandeli, Chafid. 2002. Dasar-dasar Manajemen Kepariwisataan Alam, Yogyakarta: Liberty

Dinas Pariwisata Provinsi Bali. 2018. Direktori 2018. Denpasar. Dinas Pariwisata Provinsi Bali

Dharmmesta, Basu Swastha. "Manajemen pemasaran." (2014): 1-38.

Ismayanti. 2009. Pengantar Pariwisata. Jakarta:PT Grasindo

Kismono, G. (2001). Pengantar bisnis. Edisi I, Cetakan I, BPFE, Yogyakarta.Kotler dan Amstrong.2001. Prinsip-prinsip Pemasaran. Jakarta:Erlangga.

Kotler dan Amstrong.2001. Prinsip-prinsip Pemasaran. Jakarta:Erlangga.

Marius P. Angipora. 1999. Dasar-dasar Pemasaran. Jakarta: PT Raja Grafindo Persada

Muntadliroh, Muntadliroh. "Strategi Komunikasi Pemasaran Terpadu Ekowisata Di Kebun Raya Eka Karya, Bedugul, Bali."Jurnal Master Pariwisata (JUMPA).

Schiffman, L. G., and L. L. Kanuk. "Purchasing behavior." (2007).

Sugiyono. 2012. Metode Penelitian Pendidikan. Bandung. Alfabeta

Tan, Prasadja, and Rio Budi. "Kunci Sukes Memasarkan Jasa Pariwisata." Jakarta: Esensi (2010).

Tjiptono, Fandy., Gregorius Chandra. (2011). Service, Quality, \& Satisfaction, Edisi 3 Yogyakarta: Andi. 